\title{
腐食研究のための表面分析技術の現状と今後
}

\author{
大塚俊明* \\ * 北海道大学大学院 工学研究院

\section{The Present and Future on Surface Analysis for Corrosion Study} \\ Toshiaki Ohtsuka * \\ * Faculty of Engineering, Hokkaido University

\begin{abstract}
Surface analysis for corrosion study was reviewed. For the study, the in-situ analysis was desired to describe the real feature. Light i.e., electromagnetic wave from gamma rays to infrared light has been used for the in-situ measurement of the corroded surface, although various ideas should be introduced for the study. For the application of the electromagnetic waves, a suitable window material and a suitable distance between the window and specimen surface depending on the properties of the wave must be selected. Electron spectroscopy including X-ray photoelectron spectroscopy (XPS) and Auger electron spectroscopy (AES) is not applicable for the in-situ study and, however, it is very available for the corrosion study from the following points; elemental analysis, state analysis of the element, and microscopic analysis. In future, the tip enhance Raman scattering (TERS) for which the scanning probe microscopy (SPM) is combined with the surface enhanced Raman scattering (SERS) may be useful for the in-situ corrosion study.
\end{abstract}

Key words : surface analysis, passive oxide film, corrosion product, ellipsometry, Raman spectroscopy, infrared reflection absorption spectroscopy, XPS , AES

\section{1.は じめに}

腐食現象を解明するために，多くの解析手法が使われ てきている。腐食研究での最初は，腐食量，ならびに腐 食速度の確定であるが，そのためには，化学天秤による 重量測定や電気化学手法が使われる。これらの手法はこ こでは範囲に入れない。

腐食現象を知るために，腐食表面がどのようになって いるかを知ることが重要である，腐食表面は腐食生成物 が被われているのが通常なので，表面にある腐食生成物 の測定となろう，腐食生成物の厚さにより，使う手法も 異なる. $0.1 \mathrm{~mm}$ 以上の厚さになる腐食生成物の場合に は，X線回折などの通常の機器分析が使えるので，比較 的容易に解析できる。「表面分析」として対象にするの は, $\mathrm{nm}$ オーダーから $0.1 \mathrm{~mm}$ の厚さの表面層の測定で ある。 その表面層を解析していく上で，以下の項目が解 析対象になるであろう。

組成を決める(構成原子の割合を決める)

物性を決める (電気伝導性, 半導体性質, 誘電性質, 磁気性質，光学性質など)

構造を決める(金属イオンと陰イオンの距離，金属イ オンの周りの陰イオンの配位数, 長周期の分子構造)

\section{2. 分光}

表面層の性質を決めるために，各種の分光法が考案さ れてきている，分光の本来の意味は，「光を色(波長)ご とに分ける」であるが. 現在は, 各種の電磁波(マイク

* = 060-8628 札幌市北区北 13 条西 8 丁目 (Kita 13 jo Nishi 8 chome, Kita-ku, Sapporo, 060-8628 Japan
ロ波からガンマ線までの電磁波)や粒子線(電子線，イオ ン線など)をエネルギーごとに分けることに使っている. 測定のための分光法では，入射側を分光する場合と， 検出側を分光する場合の 2 つがある.

入射側を分光する：励起する入射源のエネルギーを変 化させ，応答を入射エネルギーとその強度の関数とし て調べる。

検出側を分光する：励起後に出てくる電磁波あるいは 電子線(あるいは粒子線)のエネルギーとその強度を調 ベる.

\section{3. “in-situ”解析と “ex-situ”解析}

腐食現象を含めて, 各種分野で, その場 (in-situ) 環境 での解析が重用視されることが多い.

Table 1 に電磁波を使用した，腐食研究に使われてき ている解析手法のまとめを示す。これらの装置は，一般 的かどうかは別にして, in-situ 測定のための装置ならび にそれらの腐食研究への応用は報告されている。

一方，電子線を含む粒子線を使う手法を Table 2 にま とめる．電子線のエネルギーの分析，粒子の質量分析は 真空環境が必須であるので，その場測定に応用するには 困難である。しかし，表面層の元素の定量分析ができる ので, ex-situ 条件での応用が多数報告されている。また プラズマ状態の気体分子(グロー放電中の気体分子)によ る固体表面の剥離を利用した GDS は，固体表面層の exsitu 条件での深さ方向の分析に多用されている.

\section{4. 近紫外光 $\cdot$ 可視光・赤外光入射}

腐食系が水溶液あるいは大気環境により使える手法は 少し異なるが，近紫外光から赤外光までのエネルギーの 
Table1 Spectroscopy using electromagnetic wave.

\begin{tabular}{|c|c|c|c|}
\hline 装置名 & & 見 & での \\
\hline リプソメトリー1, 2) & $\begin{array}{l}\text { 可視光偏光の反射に } \\
\text { 伴う偏光楕円率の変 } \\
\text { 化 }\end{array}$ & $\begin{array}{l}\text { 固体表面の光学性質を } \\
\text { の表面膜の厚さ測定 }\end{array}$ & $\begin{array}{l}\text { セル } \\
\text { を入 } \\
\text { 整が }\end{array}$ \\
\hline 四仅射法 & $\begin{array}{l}\text { 可視光·紫外光の反射 } \\
\text { 率の変化 }\end{array}$ & $\begin{array}{l}\text { 寸 固体表面の光学性質を調べる. 特| } \\
\text { の表面膜の厚さ測定 }\end{array}$ & 同上 \\
\hline $\begin{array}{l}\text { 外光反射吸収分 } \\
2^{4,5)}\end{array}$ & $\begin{array}{l}\text { 赤外光の反 } \\
\text { 収 }\end{array}$ & $\begin{array}{l}\text { 反射吸収を示す赤外光のエネルギー(波数)か } \\
\text { 固体の表面層の物質の分子振動を調べる }\end{array}$ & $\begin{array}{l}\text { 糸では水 } \\
\text { 電極と } \\
\end{array}$ \\
\hline 7) & $\begin{array}{l}\text { 可視光, } \\
\text { 射·同光 } \sigma\end{array}$ & $\begin{array}{l}\text { 強し } \\
\text { 質 } 0\end{array}$ & $\begin{array}{l}\text { :する水, イオン } \\
\text { であるこれらの } \\
\text { のエ夫が必要 }\end{array}$ \\
\hline 位変調反 & $\begin{array}{l}\text { 交流によ } \\
\text { 射率の変 }\end{array}$ & $\begin{array}{l}\text { 引による反射率変化. 電極表面の電 } \\
\text {. }\end{array}$ & 飞゙, 積 \\
\hline :手法 & $\begin{array}{l}\text { 可視光 } \\
\text { 極の電 } \\
\text { 位変化 }\end{array}$ & $\begin{array}{l}\text { 電気化学系における, 光入射に伴う電流あるい } \\
\text { は電位変化 }\end{array}$ & $\begin{array}{l}\text { デジタル } \\
\text { による交 }\end{array}$ \\
\hline $\begin{array}{l}\text { 外光励起ルミネ } \\
\text { ンス分光 }{ }^{13)}\end{array}$ & $\begin{array}{l}\text { 紫外光励起 } \\
\text { 視光発光 }\end{array}$ & $\begin{array}{l}\text { バンド間励起した電子一正孔対 } \\
\text { 発光 }\end{array}$ & $\begin{array}{l}\text { 微弱光放出なの } \\
\text { また, 他の箇所 } \\
\text { 質の検討が必要 }\end{array}$ \\
\hline & $\begin{array}{l}\gamma \text { 線の吸収あるいは } \\
\text { 入射による線 } \\
\text { からの電子放出 }\end{array}$ & $\begin{array}{l}\text { マルギーを調べる. 励起エネル } \\
\text { •温度依存性から物質の同定を }\end{array}$ & $\begin{array}{l}\text { らひび } \\
\text { は薄 }\end{array}$ \\
\hline 缐吸 & 放射光X線の吸収 & $\begin{array}{l}\text { ーに伴うX線の吸収 } \\
\text { 周期構造. 物質 } \\
\text { るる }\end{array}$ & $\begin{array}{l}\text { X線透過の空材の選 } \\
\text { 層水膜を介する測定 }\end{array}$ \\
\hline 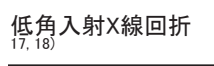 & 放射光X線の回折 & $\begin{array}{l}\text { 低角入射による表面層の回折測定から, 表面層 } \\
\text { の構造を調べる }\end{array}$ & $\begin{array}{l}\text { 同上. 水溶液系では回折パターンの明瞭さを妨 } \\
\text { 害する. }\end{array}$ \\
\hline
\end{tabular}

Table 2 Spectroscopy using electron, ionic beam, and plasma.

\begin{tabular}{|c|c|c|}
\hline 装 & 測定手法 & 見 \\
\hline & X線入 & $\begin{array}{l}\text { )から質の同定. 微 } \\
\text { から構造の }\end{array}$ \\
\hline $\begin{array}{l}\text { オージェ電子分光 } \\
\text { (OES) }\end{array}$ & & $\begin{array}{l}\text { 電子の放出エネルギ一から表面物質の同定. 入 } \\
\text { 射電子線の走査によるで表面元素のマッピング }\end{array}$ \\
\hline 質量分析 & $\begin{array}{l}\text { イオ } \\
れ た \\
\text { 分析 }\end{array}$ & $\begin{array}{l}\text { スパツタリングされた元素の同定から, 表面層の } \\
\text { 同定 }\end{array}$ \\
\hline (G & $\begin{array}{l}\text { 低圧不活性ガス中の } \\
\text { グロー放電で生成する } \\
\text { プラズマによる表面か } \\
\text { らのスパタッリング }\end{array}$ & $\begin{array}{l}\text { スパツタリングされた元素の同定から, 表面層の } \\
\text { 同定.スパツタリング元素の同定法としては,プラ } \\
\text { ズマ励起による原子発光の分光ならびに質量分 } \\
\text { 析分光などがされている. }\end{array}$ \\
\hline
\end{tabular}

電磁波(普通にいう光)を入射した時の，表 面の酸化物層で起こる現象を Fig. 1 に示す. 表面皮膜に被われた固体表面からの光反射 を測定すると，反射時に表面皮膜の吸収によ り強度減少が起こる．波長に対してこの反射 率減少を測定すると，反射分光(Reflection Spectroscopy, RS) あるいは反射吸収分光 (Reflection Absorption Spectroscopy, RAS) が得られる. 紫外光 (Ultra-Violet Light, UV), 可視光 (Vissible Light, VIS) での RAS では，固体内の電子バンド間での電子 状態の励起吸収が見られる ${ }^{3)}$. 表面皮膜が 半導体である場合には，荷電子带から伝導 体への電子励起のエネルギー(バンド間励起エネル ギー，hv)に対応した波長で吸収が見られる.

$$
h \nu \rightarrow \mathrm{h}^{+}+\mathrm{e}
$$

一方, 赤外 (IR) 光の反射の場合には, RAS 上に分子 内の原子間の振動のエネルギーに対応した波長で吸 収が見られる ${ }^{4)}$. . 振動エネルギーは分子特有なも のであるので，表面皮膜の組成同定に使える.

表面皮膜が半導体である場合には，UVあるいは VIS 照射によるバンド間励起に伴って励起正孔と電 子の対を生成する．電気化学を利用して金属/半導 体皮膜/水溶液の界面層に逆バイアスを加えると, 励起正孔一電子対は電荷分離を起して, 電気化学系 に光励起電流が流れる ${ }^{10)-12)}$. 光励起電流の測定か ら, 励起過程のエネルギーが類推可能である. 逆に, 励起正孔一電子の対が再結合する場合には, その再 結合に応じたエネルギー $\left(\mathrm{h} \nu^{\prime}\right)$ を光の形で放出する.

$$
\mathrm{h}^{+}+\mathrm{e}^{-} \rightarrow \mathrm{h} \nu^{\prime}
$$

この発光は光励起ルミネッセンスで呼ばれ，ルミネ ッセンス光の分光測定から励起エネルギーの類推も 可能となる ${ }^{13)}$. 
電気化学系で印可した交流電圧 $(E)$ と応答した交流電 流 $(i)$ の比を測定すると, 交流インピーダンス $(Z)$ が求ま る.

$$
Z=\mathrm{d} i / \mathrm{d} E
$$

電気化学では，インピーダンスを微分量で使うのが一般 であり，また，インピーダンスの交流周波数応答を電気 化学インピーダンス分光法 (Electrochemical Impedance Spectroscopy, EIS) と呼んでいる. EIS で測定する電流 には, 誘電体や半導体の空間電荷層(見掛けの誘電体層) として存在するコンデンサーに溜まる電荷 $(Q)$ の変動に 伴う電流が入っているので,

$$
i=\mathrm{d} Q / \mathrm{d} E
$$

コンデンサー容量 $(\mathrm{C})$ に関わるインピーダンスは以下の ように書ける.

$$
Z=\mathrm{d}(\mathrm{d} Q / \mathrm{d} E) / \mathrm{d} E
$$

EIS からコンデンサー容量が求まり，表面皮膜である誘 電体の厚さあるいは半導体の空間電荷層の厚さの議論が できる。

誘電体や半導体・空間電荷層の電荷変動は, その中に ある電子の濃度の変動に対応するので, 電荷変動は電子 濃度の関数である光学性質に影響を与える，電位に交流 変調を加えると, 反射率 $(R)$ が調和して変調される. こ の手法は電位変調反射 $(\mathrm{PMR})$ あるいはエレクトロレフレ クタンス (Electro-Reflectance, ER) と呼ばれる ${ }^{8), 9)}$.

$$
\mathrm{d} R / \mathrm{d} E=\mathrm{K}(\mathrm{d} Q / \mathrm{d} E)
$$

ここで, $\mathrm{K}$ は比例定数を示す. PMRからは, インピー ダンスから求めるコンデンサー容量と同様に空間電荷層 の厚さやフラットバンド電位などが求まる.

偏光を入射光に用いた場合，偏光反射時に生じる強度 減少(振幅減少) と位相遅れを利用して表面皮膜の測定が 可能である．振幅減少ならびに位相遅れが光の波の振動 面により変化するので, 偏光が作る楕円率が変化する. 反射に伴う偏光楕円率変化を測定するエリプソメトリー （楕円偏光反射解析）を使うと, 皮膜厚さをサブ nm レベ ルで決めることができる ${ }^{1), 2)}$.

入射光にレーザー光を使い, 比較的強い強度で入射すると, 表面皮膜から散乱光が放出され る. 散乱光は入射光の振動電場 ベクトルで摇らぐ分子内の電子 雲からの光放出である(レーリ 一散乱)。入射光が作る電場で 摇らいでいる電子雲に, 分子内 の原子間位置が変化する振動が 加わると, 電子雲からの光放出 には，最初の入射レーザーの光 波の振動数 ( 振動数(と)により変調された光 波 $\left(\nu \pm \nu^{\prime}\right)$ が含まれる。いわゆ, ラマン散乱光放出である ${ }^{6), 7)}$. それゆえ, 散乱光を分光分析す ると, との振動数位置に放出ピ ークが見られる。赤外吸収と同 様に振動エネルギーは分子特有 なものであるので, 物質の同定 に使える。ラマン散乱光はレー
リー散乱光に比較すると極めて微弱であるが，最近のレ ーザー技術と微弱光検出技術の進歩で困難なく測定でき るようになってきている。

\section{5. 電 子 分 光}

電子分光として, 現在, X 線光電子分光 $(\mathrm{XPS})$ ならび にオージェ電子分光 (AES) が測定手法として多用されて いる. 両者とも表面 2-3 $\mathrm{nm}$ からの電子スペクトルのみ を測定しているので，表面層のみの解析ができる，さら に, 膜厚測定や層構造解析に, アルゴンイオンスパッ夕 一による外側からの剥離技術と分光を組み合わせた測定 が使われている。

電子分光における期待される最大のことは，固体内に ある元素の状態分析である。各元素のXPSあるいは AES スペクトルは, 元素の周りに存在する他の元素の距 離と配位数により変化する.XPS では光電子スペクトル のピーク位置の微少な変化(化学シフト)が見られる. AES では, 電子放出に至るオージェ過程が少し複雑なの で，スペクトルのピーク位置変化あるいはスペクトルの 形状変化が起こる.

XPS を使った酸化物皮膜の定量解析に関する論文は非 常に多く報告されている。ここでは, 使用する立場とし て, Fe と Crに関する酸化物による化学シフトの再現性 を考えてみる. 4 グループによる化学シフトの值を Table 3 に示す。ここでは, 一番定量に使われている $\mathrm{Fe} 2 \mathrm{p}(3 / 2)$ と $\mathrm{Cr} 2 \mathrm{p}(3 / 2)$ の XPS ピークの比較である。一 番多くの報告がある, $\mathrm{Fe}_{2} \mathrm{O}_{3}$ 中の $\mathrm{Fe}$ のピーク位置は, 著者により約 $1 \mathrm{eV}$ の差がある。また, $\mathrm{Cr}_{2} \mathrm{O}_{3}$ に関しては 約 $0.5 \mathrm{eV}$ の差異が報告されている。この差異の原因は, XPSの結合エネルギー軸の検量，表面チャージアップに よるエネルギー軸のずれ，デコンボリューション(ピー ク分割)の取扱い方などが考えられる．また，これらの データも含め, 多くの論文が化学シフト值を報告してい

\begin{tabular}{|c|c|c|c|c|c|c|c|c|}
\hline \multirow{2}{*}{ Species } & \multicolumn{2}{|c|}{ Ref. 19} & \multicolumn{2}{|c|}{ Ref. 20} & \multicolumn{2}{|c|}{ Refs. 21, 22} & \multicolumn{2}{|c|}{ Ref. 23} \\
\hline & B.E./eV & Shift/eV & B.E./eV & Shift/eV & B.E./eV & Shift/eV & B.E./eV & Shift/eV \\
\hline Fe metallic & 706.8 & - & $707.0 \pm 0.2$ & - & 706.8 & - & 706.8 & - \\
\hline $\mathrm{FeO}$ & 709.0 & 2.2 & $708.4 \pm 0.3$ & 1.4 & 709.4 & 2.6 & 709.5 & 2.7 \\
\hline $\mathrm{Fe}_{3} \mathrm{O}_{4}$ & 711.0 & 4.2 & $710.0 \pm 0.3$ & 3.0 & & & & \\
\hline $\mathrm{Fe}_{2} \mathrm{O}_{3}$ & 711.0 & 4.2 & $710.7 \pm 0.2$ & 3.7 & 710.3 & 3.5 & 711.2 & 4.4 \\
\hline $\mathrm{FeOOH}$ & & & $711.5 \pm 0.3$ & 4.5 & & & & \\
\hline$\gamma-\mathrm{FeOOH}$ & 711.6 & 4.8 & & & & & & \\
\hline$\alpha-\mathrm{FeOOH}$ & 711.4 & 4.6 & & & & & & \\
\hline $\mathrm{Fe}(\mathrm{OH})_{3}$ & & & & & & & 713.2 & 6.4 \\
\hline Cr metalic & 574.1 & - & $574.1 \pm 0.1$ & - & 574.2 & - & 574.1 & - \\
\hline $\mathrm{Cr}_{2} \mathrm{O}_{3}$ & 576.5 & 2.4 & $576.1 \pm 0.1$ & 2.0 & $\begin{array}{c}576 ., 4 \\
(576.7)^{\#}\end{array}$ & $\begin{array}{c}2.2 \\
(2.5)\end{array}$ & 576.4 & 2.3 \\
\hline $\mathrm{Cr}(\mathrm{OH})_{3}$ & 577.0 & 2.9 & $577.5 \pm 0.1$ & 3.4 & & & 577.6 & 3.2 \\
\hline $\mathrm{CrO}_{3}$ & 579.1 & 5.0 & $578.2 \pm 0.2$ & 4.1 & & & & \\
\hline
\end{tabular}
るが，どれが一番真に近いかを決めることも難しい。さ

Table 3 Binding energy (B.E.) and energy shift from the metallic state for XPS peaks of Fe2p $(3 / 2)$ and $\mathrm{Cr} 2 \mathrm{p}(3 / 2)$.

\# Due to small amount of $\mathrm{OH}, 0.3 \mathrm{eV}$ shift from the original peak of $\mathrm{Cr}_{2} \mathrm{O}_{3}$ 
らに，XPSの製造会社が提供しているデータベースも同 様に会社ごとの差が存在すると予想される。デコンボリ ユーションの際の化学シフトの入れ方には注意が必要で ある。

XPS を使い, 光励起電子の脱出深さ (escape depth, あ るいは平均自由行程, mean free path)をもとに, 酸化物 と金属とのXPS シグナル強度の比から膜の厚さの推定 する方法 ${ }^{24)}$, 25), 複数の検出角度での測定から酸化物構造 を推定する方法など26)，種々の定量解析法が報告されて いる. その解析の前提として, 化学種に応じた化学シフ トの值と電子のエネルギーに依存する脱出深さが必要と なる.

AES では，励起源に電子線を使うので，XPS とは異な り $10 \mathrm{~nm}$ 径の微少部の測定が可能となる. AES の特徴を 使った測定例とし， 2 相ステンレス鋼 $(2.5 \% \mathrm{Ni}-22.8 \% \mathrm{Cr}$ -Fe)の $\alpha$ 相 (ferrite) と $\gamma$ 相 (austenite) 上の酸化物皮膜の厚 さの差異を求めた結果を Fig. 2 に示す ${ }^{16)}$. 前処理として 電解研磨 (溶液 ; 10 vol\% HClO4 + 90 vol\% ethylene-glycol monobutyl ether, 温度 ; $5^{\circ} \mathrm{C}$, 電圧; $20 \mathrm{~V}$, 時間 ; $3 \mathrm{~min}$ ) ならびにエッチング(溶液; $20 \mathrm{vol} \% \mathrm{HNO}_{3}$, 温度 ; $60^{\circ} \mathrm{C}$, 時間； $10 \mathrm{~min}$ )を施した. 前処理後に空気暴露を経て AES 装置に取り付けた. Fig. 2 では, 酸素の AES シグナ ルを Arイオンスパッターの時間に対して示している. Fig. 2 の点線は酸素の AES シグナルが最大值の半分にな るスパッター時間であり，酸化物皮膜厚さの平均に対応 する. Fig. 2 から $\alpha$ 相上の酸化物皮膜が $\gamma$ 相上のそれに比 べて $50 \%$ 程度厚くなっている. AES では, 励起源であ る電子線を X-Y 位置走査することで, AES シグナルの元 素マッピング像を描くことができ, 走査型オージェ電子 顕微 鏡(SAM ; Scanning Auger-Electron Microscopy) と 呼ばれている。しかし，SAMの性能を未だ充分に腐食 研究には使われていないようである.

\section{6. 将 来 展 望}

機器分析の腐食系への応用として，ほかにも多数の手

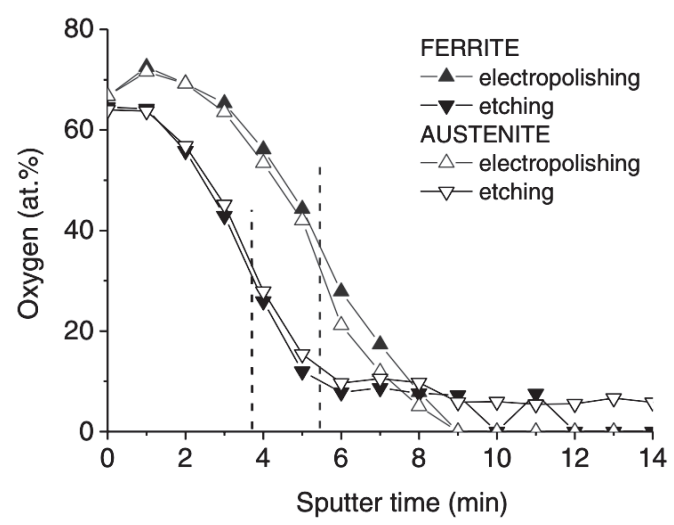

Fig. 2 Depth profile of oxygen AES signals on ferrite phase and austenite phase in duplex stainless steel. The broken lines indicate the average interface between oxide and metal. The steel was prepared by two methods of electropolishing at $20 \mathrm{~V}$ in $10 \mathrm{vol} \% \mathrm{HClO}_{4}+90 \mathrm{vol} \%$ ethyleneglycol monoburtyle ether at $5 \mathrm{C}$ for $3 \mathrm{~min}$ and etching in $20 \mathrm{vol} \%$ $\mathrm{HNO}_{3}$ at $60{ }^{\circ} \mathrm{C}$ for $10 \mathrm{~min}$. The sputter time corresponds to the thickness with a ratio of $0.42 \mathrm{~nm} \mathrm{~min}{ }^{-1}$ for $\mathrm{SiO}_{2}$.
法が使われてきている. Table 1 に挙げた， $\gamma$ 線分光を用 いたメスバウアー分光, 放射光 X 線の高輝度, 直線性を 使った低角入射回折, $\mathrm{X}$ 線吸収分光 (XAFS, XANES, EXAFS)，またTable 2 に挙げた二次イオン質量分析 (SIMS), 励起気相プラズマを使ったグロー放電分光法 (GDS) も腐食・腐食生成物研究に使われている。このう ち, 電磁波であるX 線や $\gamma$ 線の分光では, in-situ 分析の ためのセル, 装置改良が報告されている，機器分析では, 真空状態での測定が一番感度・安定性が高い. 空気中, さらに水溶液中となる，ノイズレベルやバックグランド 信号の増加があり，安定した測定を短時間で行うには困 難を伴うが, 今後の測定法の改良により多くの応用が可 能となると期待される.

環境を選ばずに, 微少領域の描画とともに物質の分 析・同定ができる分析手法が腐食屋として夢であるが, 未だ実現はしていない. 将来の分光法として, 著者は, $\operatorname{SPM}($ 走査プローブ顕微鏡) と SERS (表面増強ラマン散 乱)とを結び付けたTERS(Tip Enhance Raman Scattering) に非常に期待している(Fig. 3) 27),28). TERS は，阪大の河 田 聡教授(現名誉教授, ナノフォトン(株)の創業者)の 考案した装置であり，既に国内外のメーカーから製造発 売されている.SPMの探針に金属蒸着し, レーザー光 で探針の先端に誘起される電場を使って端子近傍にある 物質のラマン散乱を増強させる手法である。気相系では Tip 近傍にある固体表面からラマン散乱光を充分な感度 で測定でき, Tip 先端のサイズに応じるが $10 \mathrm{~nm}$ 程度の 微少部での分析は可能といわれている。水溶液中にある 固体表面の測定は未だ報告はほとんどないが，試みる価 值は充分あるであろう。

\section{7. ま と め}

金属腐食の研究において, 腐食生成物を同定していく ことが重要である. $\mathrm{mm}$ 厚さ以上の腐食生成物には多く の解析手法を使っていくことができる，一方，不働態皮 膜のような $10 \mathrm{~nm}$ 以下の表面薄膜の場合には表面分析の 領域になる，腐食の“その場 (in-situ)” 測定の条件を入 れると測定方法はかなり限定される．測定セルや測定条 件を工夫する必要があるが, $\gamma$ 線から赤外光までの幅広 いエネルギーの電磁波を使う手法は in-situ 測定が可能で ある。

XPS や AES のような電子分光は測定に真空環境を必

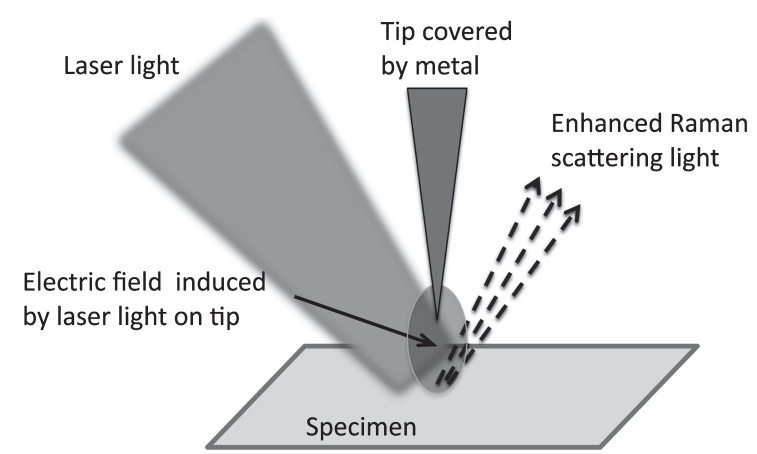

Fig. 3 Schematic model of tip enhanced Raman scattering (TERS) in scanning probe microscopy (SPM). 
要とするので, in-situ 測定はできないが, ex-situ 条件下 での薄膜の元素状態分析に威力を発する.

将来的には, in-situ 条件での微小部の解析ができるこ とが望まれる．SPM(走査プローブ顕微鏡）と SERS(表面 増強ラマン散乱) とを結び付けた TERS(端子増強ラマン 散乱) は in-situ 微小部解析のための候補になるであろう.

\section{参 考 文 献}

1) T. Ohtsuka, Zairyo-to-Kankyo, 42, 663 (1993).

2) T. Ohtsuka, J. Surf. Finish. Soc. Japan, 43, 429 (1992).

3) K. E. Heusler and T. Ohtsuka, Surface Sci., 101, 194 (1980).

4) J. Itoh, T. Sasaki, T. Ohtsuka and M. Osawa, J. Electroanal. Chem., 473, 256 (1999).

5) T. Sasaki, J. Itoh, Y. Horiguchi and T. Ohtsuka, Corros. Sci., 48, 4339 (2006)

6) T. Ohtsuka, Zairyo-to-Kankyo, 42, 592 (1993).

7) T. Ohtsuka, J. Surf. Finish. Soc. Japan, 40, 1000 (1989).

8) T. Ohtsuka, Y. Sasaki and A. Hyono, Electrochimica Acta, 131,116 (2014).

9) N. Hara and K. Sugimoto, J. Electrochem. Soc., 138, 1594 (1991).

10) K. Azumi, T. Ohtsuka and N. Sato, J. Electrochem. Soc., 133, 1326 (1986).

11) K. Azumi, T. Ohtsuka and N. Sato, Corros. Sci., 31, 715 (1990).

12) H. Tsuchiya, S. Fujimoto and T. Shibata, J. Electroceramics, 16, 49 (2006)

13) M. Ueda and T. Ohtsuka, Corros. Sci., 44, 1633 (2002).

14) M. Stratmann and H. Hoffmann, Corros. Sci., 29, 1329 (1989).

15) G. G. Lomg, J. Kruger, M. Katayama and D. R. Black, J Electrochem. Soc., 130, 314 (1983).
16) A. J. Davenport and M. Sansone, J. Electrochem. Soc., 142, 750 (1995).

17) M. Sato, M. Kimura, M. Yamashita, H. Konishi, S. Fujimoto, Y. Tabira, T. Doi, M, Nagoshi, S. Suzuki, T. Kamimura, T. Nakayama and T. Ohtsuka, Passivation of Metals and Semiconductors, Properties of Thin Oxide Layers, p. 95 P. Marcus and V. Maurice (Editors), Elsevier B. V. (2006).

18) M. Yamashita, H. Konishi, T. Kozakura, J. Mizuki and H. Uchida, Corros. Sci., 472492 (2005).

19) K. Asami and K. Hashimoto, Corros. Sci., 18, 151 (1978).

20) C. Donic, A. Kocijan, D. Mandrino and M. Jenko, Metallurgy and Materials Transactions B, 42, 1044 (2011).

21) V. Morrice, W. P. Yang and P. Marcus, J. Electrochem. Soc., 143, $1182(1996)$.

22) V. Morrice, W. P. Yang and P. Marcus, J. Electrochem. Soc., 141, 3016 (1994).

23) R.-H. Jung, H. Tsuchiya and S. Fujimoto, Corros. Sci., 58, $62(2012)$.

24) K. Asami, K. Hashimoto and S. Shimodaira, Corros. Sci., 18, 151(1978).

25） K Asami, J. Surf. Sci. Soc. Jpn., 19, 307 (1998).

26) J. Högström, W. Fredriksson, K. Edstrom, F. Björefors, L. Nyholm, and C.-O. A. Olsson, Applied Surface Science, 284, 700 (2013).

26) V. Vignal, H. Krawiec, S. Le Manchet and J. Sol. State Electrochem., 18, 2947 (2014).

27) http://nanophoton.jp/products/terssense/index.html

28) J. Ando, T. Yana, K. Fujita and S. Kawata, Phys. Chem. Chem. Phys., 15, 13713 (2013).

(2015 年 2 月 2 日受理)

\section{要旨}

腐食研究のための表面分析技術の現在の状況を要約した。腐食反応で生成した腐食生成物の測定には, in-situ (その場) 測定が望まれる. 光, つまりガンマ線から赤外光まで電磁波を使う測定では, 工夫が必要 であるが, in-situ測定がなされてきている，電磁波の性質により，空材の選択や空材の試料表面との距離 などの調整が必要である．X線光電子分光 $(X P S)$ やオージェ電子分光 (AES) などの電子分光法では, in-situ 測定はできないが, 元素分析, 元素の状態分析, 微少部分析などの特徵があるので, 有用である. 将来的には, 表面増強ラマン散乱 $(\mathrm{SERS})$ と走査型プローブ顕微鏡 $(\mathrm{SPM})$ を結び付けたチップ増強ラマン 散乱 (TERS)の使用が腐食反応の in-situ 測定に利用できる可能性がある.

キーワード 表面分析, 不働態酸化物皮膜, 腐食生成物, エリプソメトリー, ラマン分光, 赤外反射 吸収分光，XPS，AES 